Esta revista forma parte del acervo de la Biblioteca Jurídica Virtual del Instituto de Investigaciones Jurídicas de la UNAM

\title{
Fidelity to our Imperfect Constitution: a Response to Five Views*
}

\section{Fidelidad a nuestra Constitución imperfecta: una respuesta a cinco visiones}

\author{
James E. FLEMING**
}

\section{Resumen:}

En mi libro reciente, Fidelity to Our Imperfect Constitution, adelanto una crítica sostenida al originalismo en todas sus formas y defiendo tanto lo que Ronald Dworkin llamó una "lectura moral" de la Constitución de los Estados Unidos de América como lo que, junto a Sotirios A. Barber, he llamado una "aproximación filosófica" a la interpretación constitucional. En este ensayo para el Simposio sobre el libro, respondo a cinco comentarios muy pensados. Primero, en contra del comentario de Sot Barber, justifico el responder a la "resurgencia persistente del originalismo" y el tratar de "salvar al originalismo nuevo de sí mismo" al demostrar el grado hasta el cual muchos reconocen la necesidad de hacer juicios morales en la interpretación constitucional. Segundo, en atención al comentario de Imer Flores, esbozo una distinción entre ser un lector moral sistemático y reconocer la necesidad de hacer juicios normativos en la interpretación constitucional. Tercero, resisto la interpretación y crítica de mi proyecto de Ken Kersch como "llamado a luchar" por el "aspiracionalismo" encima del "historicismo", cuando quiero argumentar por la superioridad de las lecturas morales (las cuales combinan lo que él llama "aspiracionalismo" o justificación e "historicismo" o "ajuste") sobre los originalismos. Cuarto, acojo el análisis cuidadoso de Linda McClain de los originalismos versus las lecturas morales en Obergefell v. Hodges (2015), al proteger el derecho fundamental a contraer matrimonio para las parejas del mismo sexo, como una confirmación del argumento de que el "originalismo inclusivo" incluye prácticamente todo lo que un lector moral con probabilidad argumentaría. Finalmente, en respuesta a Lawrence Sager, acentúo las afinidades entre su bien conocida teoría constitucional

* Artículo recibido el 9 de mayo de 2016 y aceptado para su publicación el 10 de octubre de 2016.

** The Honorable Paul J. Liacos Professor of Law, Boston University School of Law. I wish to thank Imer Flores for organizing a conference on the penultimate draft of my book at the National Autonomous University of Mexico (UNAM) on February 1617,2015 . The papers included in this symposium were originally prepared for that conference. I published a previous version of this paper in (2016) 31 Constitutional Commentary 479. 
Esta revista forma parte del acervo de la Biblioteca Jurídica Virtual del Instituto de Investigaciones Jurídicas de la UNAM

JAMES E. FLEMING

"buscar-justicia" y mi lectura moral, y argumento que ambas teorías reflejan concepciones de la fidelidad como honrando nuestros principios aspiracionales, no simplemente como siguiendo nuestras prácticas históricas en la forma de originalismos convencionales.

\section{Palabras clave:}

Interpretación constitucional, fidelidad en la interpretación constitucional, lectura moral de la Constitución, teoría constitucional buscar-justicia, originalismo, precedente.

\section{Abstract:}

In my recent book, Fidelity to Our Imperfect Constitution, I put forward a sustained critique of originalism in all its forms and defend what Ronald Dworkin called a "moral reading" of the U. S. Constitution and what Sotirios A. Barber and I have called a "philosophic approach" to constitutional interpretation. In this essay for the UNAM symposium on the book, I reply to five thoughtful commentaries. First, as against Barber's commentary, I justify responding to the "persistent resurgence of originalism" and attempting to "save the new originalists from themselves" by showing the extent to which many of them acknowledge the need to make moral judgments in constitutional interpretation. Second, in appreciation of Imer Flores's commentary, I draw a distinction between being a systematic moral reader and acknowledging the need to make normative judgments in constitutional interpretation. Third, I resist Ken Kersch's interpretation and criticism of my project as "calling the fight" for "aspirationalism" over "historicism"-I mean instead to argue for the superiority of moral readings (which combine what he calls "aspirationalism" or justification and "historicism" or fit) over originalisms. Fourth, I embrace Linda McClain's careful analysis of originalisms versus moral readings in Obergefell v. Hodges (2015), protecting the fundamental right to marry for same-sex couples, as confirming my argument that "inclusive originalism" includes practically everything that a moral reader would be likely to argue for. Finally, in response to Lawrence Sager, I bring out the affinities between his well-known "justice-seeking" constitutional theory and my own moral reading, and I argue that both theories reflect conceptions of fidelity as honoring our aspirational principles, not simply following our historical practices in the manner of conventional originalisms.

Keywords:

Constitutional interpretation, fidelity in constitutional interpretation, moral reading of a Constitution, justice-seeking constitutional theory, originalism, precedent. 
Esta revista forma parte del acervo de la Biblioteca Jurídica Virtual del Instituto de Investigaciones Jurídicas de la UNAM

SUMmARY: I. Introduction. II. Barber: responding to the "Persistent resurgence of originalism". III. Flores: the best understanding of fidelity. IV. Kersch: "Call[ing] the fight" for moral readings over originalisms. V. McClain: moral readings versus originalisms in Obergefell: The "Empty Cupboard" of conventional originalisms. VI. Sager: fidelity to "a better version of ourselves". VII. Conclusion. VIII. Bibliography.

\section{INTRODUCTION}

I am deeply grateful to Problema for publishing this symposium on my recent book, Fidelity to Our Imperfect Constitution: For Moral Readings and Against Originalisms. ${ }^{1}$ In the book, I put forward a sustained critique of originalism - whether old or new, concrete or abstract, living or dead. Instead, I defend what Ronald Dworkin called a "moral reading" of the U.S. Constitution ${ }^{2}$ and what Sotirios A. Barber and I have called a "philosophic approach" to constitutional interpretation. ${ }^{3}$ By "moral reading" and "philosophic approach", I refer to conceptions of the Constitution as embodying abstract moral and political principles - not codifying concrete historical rules or practices - and of interpretation of those principles as requiring normative judgments about how they are best understood - not merely historical research to discover relatively specific original meanings. Through examining the spectacular concessions that originalists have made to their critics, I show the extent to which even they acknowledge the need to make normative judgments in constitutional interpretation. I argue that fidelity in interpreting the Constitution as written requires a moral reading or philosophic approach, not

1 James E. Fleming, Fidelity to Our Imperfect Constitution: For Moral Readings and Against Originalisms (Oxford University Press 2015).

2 Ronald Dworkin, Freedom's Law: The Moral Reading of the American Constitution 2-3 (Harvard University Press 1996).

3 Sotirios A. Barber \& James E. Fleming, Constitutional Interpretation: The Basic Questions xii, 155-170 (Oxford University Press 2007). 
Esta revista forma parte del acervo de la Biblioteca Jurídica Virtual del Instituto de Investigaciones Jurídicas de la UNAM

any version of originalism or living constitutionalism. Fidelity commits us to honoring our aspirational principles, not following the relatively specific original meanings (or original expected applications) of the founders. Originalists would enshrine an imperfect Constitution that does not deserve our fidelity. Only a moral reading or philosophic approach, which aspires to interpret our imperfect Constitution so as to make it the best it can be, gives us hope of interpreting it in a manner that may deserve our fidelity. ${ }^{4}$

The essays included here were originally drafted for a wonderful symposium Imer Flores organized on the penultimate draft of the book at the National Autonomous University of Mexico (UNAM). I benefitted greatly from the commentaries there by Sotirios A. Barber, Imer Flores, Ken I. Kersch, Linda C. McClain, and Larry Sager (all of which are published here in revised form), as well as those by Richard Fallon and Larry Solum. I revised the book significantly based on criticisms Fallon and Solum made in draft papers and remarks at the UNAM conference that are not published here. Fallon's paper made clear how important it was for me to stress that my conception of fidelity in constitutional interpretation is not theological or religious in the way that Jack Balkin's conceptions of constitutional faith, fidelity, and redemption seem to be. ${ }^{5}$ His paper was so cogent that I completely accepted his criticisms and accordingly revised the book throughout. Therefore, having concluded that his essay had accomplished its constructive purpose, he quite sensibly decided not to publish it. Solum's remarks prompted me to clarify that in my book, I am addressing his programmatic account of "the new originalism" as a family of theories in his book, Constitutional Originalism. I am not addressing his own theory of originalism, which he has been developing in a number of works, published and unpublished, over the years. I understand, from conversations with Solum, that he plans to elaborate his own theory of originalism in three

4 Fleming (n 1) xi, 3.

5 Richard Fallon, The Rhetoric of Constitutional Theology, draft prepared for the conference on the penultimate draft of this book, held at the National Autonomous University of Mexico. 
Esta revista forma parte del acervo de la Biblioteca Jurídica Virtual del Instituto de Investigaciones Jurídicas de la UNAM

books to be published over a number of years. I shall take up the essays in alphabetical order.

\section{BARBER: RESPONDING TO THE "PERSISTENT RESURGENCE OF ORIGINALISM"}

In 2007, Barber and I published a book, Constitutional Interpretation: The Basic Questions, in which we took up Dworkin's famous call for a "fusion of constitutional law and moral theory", arguing for a philosophic approach to constitutional interpretation. ${ }^{6}$ In doing so, we systematically analyzed competing approaches - textualism, consensualism, originalism, structuralism, doctrinalism, minimalism, and pragmatism - that aim and claim to avoid making moral and philosophic judgments about the best understanding of the Constitution. We argued for a "fusion of approaches": "Within such a fusion, we... understand text, consensus, intentions, structures, and doctrines not as alternatives to but as sites of philosophic reflection and choice about the best interpretation and construction of our constitutional commitments". ${ }^{7}$

This book is a sequel or companion to Barber's and my prior book. In this book, I criticize particular originalisms in a more thoroughgoing way and demonstrate the concessions many originalists have made to the moral reading or philosophic approach. Furthermore, I elaborate the place and constructive uses of original meaning, precedent, and tradition in a philosophic approach. I also recast leading conceptions of living constitutionalism as moral readings that strive to be faithful to the best understanding of the Constitution. I engage especially with new varieties of originalism and living constitutionalism that have emerged more fully since that prior book was completed. ${ }^{8}$

Barber says that, since 2007, he has excused himself from the debate with "the so-called new originalisms" until now "because [he]

6 Barber \& Fleming (n 3) xiii.

7 Ibid. at 190.

8 Fleming (n 1) xi-xii. 
Esta revista forma parte del acervo de la Biblioteca Jurídica Virtual del Instituto de Investigaciones Jurídicas de la UNAM

thought that there was little to be said about constitutional interpretation that hasn't been said" and because he thought "one and only one approach" to constitutional interpretation "makes sense", namely, the approach Dworkin, Barber, and I have defended. ${ }^{9}$ Even if Barber is right that there was "little to be said... that hasn't been said", I think it may be worthwhile to repeat (and, where necessary, reformulate) what we said before in order to rebut the new originalisms that have spring from the hydra head of originalism. Indeed, since 2007, many people have claimed to be saying something new in defense of new originalisms. I have been invited to a number of conferences assessing these new originalisms. Instead of sitting on the sidelines and simply saying, "read Barber's and my 2007 book, Constitutional Interpretation: The Basic Questions", I have thought it important to participate in these debates with the new originalists, reformulating our arguments in defense of a philosophic approach and criticizing their new formulations.

Barber acknowledges that "there are questions to ask about the persistent recurrence of originalism". ${ }^{10} \mathrm{He}$ also observes that I "revisit... the interpretative debate to save new originalists from themselves". ${ }^{11}$ Indeed I do. I believe there is value in showing the extent to which many of the new originalists acknowledge the need to make moral judgments in constitutional interpretation, even as they claim to be rejecting moral readings.

Barber further states: "What I fail to understand is Jim's optimism about the future of constitutional theory in the face of the cultural and intellectual barriers to the one mode of interpretation that makes sense".12 He also has reservations about my optimism in the face of political dysfunction and looming constitutional failure. ${ }^{13}$ Admittedly, my disposition may seem more optimistic than Barber's, but my views on failure and fidelity may not be as far from his analysis as he suggests. As Barber notes, I acknowledge that

9 Sotirios A. Barber, 'On Jim Fleming's Anti-Originalism' (2017) 11 Problema 23.

10 Ibid. 3.

11 Ibid. 6.

12 Ibid. 6 and 7.

13 Ibid. 7-9. 
Esta revista forma parte del acervo de la Biblioteca Jurídica Virtual del Instituto de Investigaciones Jurídicas de la UNAM

"a clear form of failure would be a people's loss of the capacity to change or reform a constitution".14 And I recognize that the Constitution may have contributed to our present dysfunction through its failure adequately to sponsor a formative project of cultivating the civic virtues and the capacities needed to maintain constitutional self-government. Indeed, I suggest that our best hope for averting constitutional failure may be, not to rewrite the Constitution, but to rewrite the constitutional culture through reinvigorating such a formative project. ${ }^{15}$ And so, I agree with Barber that "constitutional fidelity rests on hopes for cultural change". ${ }^{16}$ The only place where I disagree with him is that he believes this "would fall short of a real argument for constitutional fidelity", ${ }^{17}$ whereas I think it stems from an argument for constitutional fidelity —if we understand fidelity as honoring our aspirational principles, not merely following our historical practices. ${ }^{18}$ I start from where we are: as citizens working within our constitutional practice, adopting an attitude of fidelity toward the Constitution despite its imperfections, trying to interpret it so as to honor its commitments and make it the best it can be.

\section{FLORES: THE BEST UNDERSTANDING OF FIDELITY}

Imer Flores's thoughtful essay - through addressing the basic question I raised, Who is to interpret the Constitution? - recognizes the breadth of a moral reading of the Constitution as contrasted with a dispute resolution model of courts narrowly deciding the cases before them. ${ }^{19}$ Every author must hope for readers as careful and sympathetic as Flores. His interpretive charity and generosity of spirit in engaging with my book recall for me the warm hospitality with

14 Ibid. 8.

15 Fleming (n 1) 170, 184, 187.

16 Barber (n 9) 8.

17 Ibid. at 9.

18 Fleming (n 1) 20, 105-6, 137-38, 189, 191.

19 Imer B. Flores, 'Constitutional Interpretation, Intelligent Fidelity, and (Im) Perfection: On James E. Fleming's Fidelity to Our Imperfect Constitution' (2017) 11 Problema 31-57. 
Esta revista forma parte del acervo de la Biblioteca Jurídica Virtual del Instituto de Investigaciones Jurídicas de la UNAM

JAMES E. FLEMING

which he hosted the symposium on the penultimate draft of it at UNAM. His essay prompts me to acknowledge two significant points.

First, Flores's observations in his opening comments at the UNAM symposium led me to make subtle and nuanced revisions throughout the book, especially with respect to my rhetorical strategies of pitting moral readings against originalisms. Flipping the originalists' rhetorical strategy of asking, "Are we all originalists now?", I had examined the spectacular concessions that originalists have made to their critics and asked, "Are we all moral readers now?" Flores's remarks prompted me to recast my argument to say - whether or not we are all moral readers now, which might mistakenly imply that we all have systematic, coherent moral readings - we all (including originalists) now acknowledge the need to make normative judgments in constitutional interpretation. ${ }^{20}$

Second, reading Flores's sympathetic explication of Dworkin's moral reading as well as my own recalls for me the excitement I experienced when I originally read Dworkin's Taking Rights Seriously upon its publication in 1977. Although other readers may have been most moved by the passages about "taking rights seriously", I was captivated by the power of Dworkin's rhetorical strategy of seeking to reclaim the virtue of fidelity in constitutional interpretation from "the jurisprudence of Richard Nixon", a form of proto-originalism manifested in the constitutional views of Nixon's first nominee to the Supreme Court, Justice William Rehnquist. ${ }^{21}$ The passages Imer quotes from Taking Rights Seriously concerning fidelity were the inspiration for my co-organizing a major symposium on "fidelity in constitutional interpretation" for Fordham Law Review featuring Dworkin as the keynote speaker. ${ }^{22}$ Those passages and the conference itself in turn were the inspiration for my writing the book, $\mathrm{Fi}^{-}$ delity to Our Imperfect Constitution. Flores shows more fully than I

20 See, e. g., Fleming (n 1) 3, 126.

21 See Ronald Dworkin, Taking Rights Seriously 131-49 (Harvard University Press 1977).

22 See 'Symposium on Fidelity in Constitutional Theory' (1997) 65 Fordham L. Rev. 1249, in particular, Ronald Dworkin, 'The Arduous Virtue of Fidelity: Originalism, Scalia, Tribe, and Nerve' (1997) 65 Fordham L. Rev. 1249. 
Esta revista forma parte del acervo de la Biblioteca Jurídica Virtual del Instituto de Investigaciones Jurídicas de la UNAM

did in my book that the aspiration to fidelity was there from the beginning in Dworkin's work. Flores also instructively invokes the work of Lon Fuller distinguishing between "intelligent" and "unintelligent" fidelity. ${ }^{23}$ Whether or not Fuller's ideas on "positivism and fidelity to law" and "the morality of law" ${ }^{24}$ influenced Dworkin's initial formulations, they certainly were an important antecedent for them. Flores is right to bring Fuller's ideas to bear on the arguments for moral readings and against originalisms.

\section{KERSCH: "CALL[ING] THE FIGHT" FOR MORAL READINGS OVER ORIGINALISMS}

Ken Kersch is an astute intellectual historian of American political and constitutional development. Accordingly, I am gratified that he concludes that "Fleming's important book breaks new ground in its prominent attempt at synthesis" between the "aspirationalism" of moral readings and the "historicism" of originalisms and that it is a "thoughtful, timely, and engaging contribution to understanding the way we live now in the United States, and in U. S. constitutional theory". ${ }^{25}$ Relatedly, since many critics seem to assume that moral readings are inherently utopian and not adequately grounded in our constitutional practice, I am delighted that he views my book as an advance that, through reckoning more fully with "fit" with historical materials, has made a moral reading more cogent — that I have made a "laudable attempt to walk [my]self back" from liberal constitutional theory that has been "very far out on that plank". ${ }^{26}$

23 Flores (n 19) 21-22 (quoting and discussing Lon L. Fuller, "The Case of the Speluncean Explorers' (1949) 62 Harv. L. Rev. 616, 625-26).

24 See Lon L. Fuller, The Morality of Law (Yale University Press 1969 rev. ed. 1977); Lon L. Fuller, 'Positivism and Fidelity to Law-A Reply to Professor Hart' (1958) 71 Harv. L. Rev. 630.

25 Ken I. Kersch, 'Originalism's Curiously Triumphant Death: The Interpenetration of Aspirationalism and Historicism in U.S. Constitutional Development' (2017) 11 Problema, 79.

26 Ibid. 2. 
Esta revista forma parte del acervo de la Biblioteca Jurídica Virtual del Instituto de Investigaciones Jurídicas de la UNAM

Kersch criticizes me, though, for striving to "call the fight" 27 for aspirationalism over historicism. I need to draw a distinction here. I did not mean to "call the fight" for aspirationalism over historicism, but I confess that I did indeed mean to argue for the superiority of moral readings over originalisms. To explain the distinction: I argued that in our constitutional culture, the use of history - what Kersch calls "historicism" - is not originalist. ${ }^{28}$ Here I took a page out of Jack Balkin's extraordinarily rich analysis of the uses of history in our constitutional practice: that it does not function as originalists, old and new, assume or claim it does. To the contrary, he offered a typology of eleven "styles of justification", many of which use history in weaving aspirationalism together with historicism. ${ }^{29}$ I also contended that a moral reading could and should incorporate such uses of history -in fitting and justifying our constitutional practice. This is the concern for "fit" or "historicism" in my moral reading or "aspirationalism" that Kersch applauds.

Again, I acknowledge that I did try to "call the fight" for moral readings over originalisms. I argue that moral readings are more faithful to our Constitution and our constitutional practice than originalisms. Moreover, I contend that many "new originalisms" are best understood as moral readings. But I was not thereby trying to "call the fight" for aspirationalism over historicism. ${ }^{30}$ Instead, I was presenting a philosophic approach as a "fusion of approaches" that incorporates its "historicism" into its "aspirationalism" by reckoning seriously with "fit" with historical materials in a moral reading. ${ }^{31}$ And I was arguing in favor of moral readings' conception of fidelity as honoring our aspirational principles, over and against originalist conceptions of it as following our historical practices. ${ }^{32}$ Perhaps my way of framing the debates and my arguments was more polemical

27 Ibid. 2, 21.

28 Fleming (n 1) 136-40.

29 Jack M. Balkin, 'The New Originalism and the Uses of History' (2013) 82 Fordham L. Rev. 641, 659-60.

30 Kersch (n 25) 2, 21.

31 Fleming (n 1) 33, 106-08, 136-40.

32 Ibid. 20, 105-6, 137-38, 189, 191. 
Esta revista forma parte del acervo de la Biblioteca Jurídica Virtual del Instituto de Investigaciones Jurídicas de la UNAM

than necessary, as in the subtitle of my book, "for moral readings and against originalisms". ${ }^{33}$

Finally, Kersch relates my book to the Rawlsian and Dworkinian projects in constitutional theory to which I have contributed in previous books. ${ }^{34} \mathrm{He}$ characterizes my project as "mopping up" and trying to show that my concern for fidelity, fit, and justification was there in Rawls and Dworkin "all along". ${ }^{35}$ Although, as just noted, Flores's essay explicates some of the antecedents in Dworkin's work for the moral reading I develop in my book, my project is not to "mop up" or to attribute my concern for fidelity to Rawls and Dworkin. My work is, indeed, broadly speaking, Rawlsian and Dworkinian. But my aim is not to put forward an exegesis of Rawls's or Dworkin's work. Instead, I have developed a philosophic approach inspired by, and in the spirit of, the general frameworks of Rawls and Dworkin. I ask the reader to assess my arguments on their own terms - and in terms of whether I offer a recognizable and attractive account of our constitutional practice - not in terms of whether I have been true to Rawls or Dworkin's work or whether I have tidily "mopped up" after them.

\section{MCCLAIN: MORAL READINGS VERSUS ORIGINALISMS \\ IN OBERGEFELL: THE "EMPTY CUPBOARD” OF CONVENTIONAL ORIGINALISMS}

I appreciate Linda McClain's careful analysis of originalisms versus moral readings in Obergefell $v$. Hodges (along with the decision it overruled, DeBoer v. Snyder), the recent Supreme Court decision recognizing that the fundamental right to marry extends to gays and lesbians. ${ }^{36}$ Her paper richly substantiates two claims I made in

33 Ibid. iii.

34 See, e. g., James E. Fleming, Securing Constitutional Democracy: The Case of Autonomy (University of Chicago Press 2006); James E. Fleming \& Linda C. McClain, Ordered Liberty: Rights, Responsibilities, and Virtues (Harvard University Press 2013).

35 Kersch (n 25) 3.

36 Linda C. McClain, 'Reading DeBoer and Obergefell through the "Moral Readings versus Originalisms" Debate: From Constitutional "Empty Cupboards" to Evolving 
Esta revista forma parte del acervo de la Biblioteca Jurídica Virtual del Instituto de Investigaciones Jurídicas de la UNAM

my book. First, that the new originalists who argue that cases like Obergefell are not "anti-originalist" but indeed are compatible with originalism - the "inclusive originalists" - are engaging in moral readings and are trying to rid their originalisms of the baggage of Justice Antonin Scalia's and Judge Robert Bork's exclusive originalisms. Second, that the exclusive originalists are not going to be persuaded by these new "inclusive originalist" arguments. ${ }^{37}$

Three things that come out in McClain's analysis are telling. First, when some new, inclusive originalist scholars filed an amicus brief in Obergefell making "abstract originalist" arguments for extending the fundamental right to marry to gays and lesbians, other (more conventional) exclusive originalist scholars filed an amicus brief counter-arguing that this abstract originalism is more in line with Dworkin's anti-originalist moral reading than with a true originalism..$^{38}$ Second, neither of the originalist judges on the Supreme Court -Justice Scalia and Justice Thomas - was moved one inch by these inclusive originalist arguments, nor were Chief Justice Roberts and Justice Alito. ${ }^{39}$ Third, the majority opinion, by Justice Kennedy, was not moved in the slightest by these arguments and was not at all originalist in any conventional sense. Instead, his opinion exemplifies a moral reading..$^{40}$ To be sure, history matters in Kennedy's opinion. But the history that matters is history as evolving contemporary consensus moving away from the history that the originalists say is relevant, that of the relatively specific original meaning of the Fourteenth Amendment in 1868. That is, the history that matters is that of evolving contemporary consensus working toward better understandings of our constitutional commitments - not history of the founding as an authoritative source that decides our questions for us (or that we must follow). ${ }^{41}$

Understandings' (2017) 11 Problema 85-130 (analyzing Obergefell v. Hodges, 135 S. Ct. 2584 (2015), and DeBoer v. Snyder, 772 F. $3 d 388$ (6 $6^{\text {th }}$ Cir. 2014)).

37 Fleming (n 1) 16-19.

38 McClain (n 36) 27-33.

39 Ibid. 33 and 34.

40 Ibid. 34 and 35.

41 Ibid. 35-49. 
Esta revista forma parte del acervo de la Biblioteca Jurídica Virtual del Instituto de Investigaciones Jurídicas de la UNAM

McClain's analysis makes all of these points as plain as day. Originalism in any conventional sense remains, as Justice Ginsburg put it, "an empty cupboard" 42 as far as sex equality and equality for gays and lesbians are concerned. The most jaw-dropping statement I have ever read in constitutional theory is William Baude's "inclusive originalist" suggestion to the contrary that "Obergefell seemed to pick the originalist route". 43 This confirms my analysis in the book that his inclusive originalism includes practically everything that a moral reader would be likely to argue for in our constitutional culture. $^{44}$

\section{SAGER: FIDELITY TO “A BETTER VERSION OF OURSELVES"45}

I read Sager's essay as being in the nature of a concurring opinion. For I view Sager, along with Barber, as the leading proponents of a moral reading, philosophic approach, or justice-seeking account working in constitutional theory today. In my development of the moral reading, I simply adopted Sager's highly instructive account of the thinness or moral shortfall of constitutional law as compared with our thicker conceptions of constitutional justice and of justice generally. I also developed a form of what he has called a "justiceseeking" constitutional theory: in which courts, legislatures, executives, social movements, and citizens generally are partners in building out our constitutional practice to honor the best understanding of our constitutional commitments. ${ }^{46}$

42 Ibid. 8 (quoting Ruth Bader Ginsburg, 'Sexual Equality Under the Fourteenth and Equal Rights Amendments' 1979 Wash. U. L. Q. 161, 164).

43 William Baude, 'Is Originalism Our Law?' (2015) 115 Colum. L. Rev. 2349, 2382 .

44 Fleming (n 1) 1, 15-19.

45 Lawrence Sager, 'Delegation in our Justice-Seeking Constitution' (2017) 11 Problema, 147.

46 Fleming (n 1) 89-90 (incorporating arguments from Lawrence G. Sager, Justice in Plainclothes: A Theory of American Constitutional Practice (Yale University Press 2004)). 
Esta revista forma parte del acervo de la Biblioteca Jurídica Virtual del Instituto de Investigaciones Jurídicas de la UNAM

Sager's opening formulation about the relationship between the text of the Constitution and our constitutional practice is exactly right: "[T] he text is in service of our practice; our practice is not in service of the text... at least not until we arrive at the conclusion that our practice is best served by an understanding that connects us to the text in this dominating way". ${ }^{47}$ That is a characteristically incisive formulation that hones in on what is wrong with many varieties of originalism: they fail to understand the purpose of our constitutional practice. From Sager's perspective, I may give "too little weight" to precedent in our constitutional practice. ${ }^{48}$ I was walking a tightrope between viewing precedent as an obligation (responding to Abner Greene's criticism) and viewing it as a factor or resource to be taken into account in constructing the best interpretation of our constitutional commitments (incorporating Balkin's account). ${ }^{49}$ I may have slipped on that tightrope and he may be right that a moral reading should give precedent more weight than my account did.

But Sager and I may not be as far apart as it might look. After all, I did contend, in the spirit of Sager, that proponents of common-law constitutional interpretation typically give greater weight to precedent than originalists do. ${ }^{50}$ And I did present my moral reading as a form of such common-law constitutional interpretation. ${ }^{51}$ I suppose two things may account for the rhetorical distance between Sager and me with respect to precedent. One, perhaps my intense engagement with originalists - and argument that moral readers are more faithful to the text than are originalists - led me to emphasize text more than he does. Two, although I fully recognize and insist that we build out our constitutional practice over time, making judgments expressed through precedents, I was not putting forward a theory of precedent as such and therefore I did not advance the usual justifications for following precedent (including those typically associated with common-law constitutional interpretation). That may make it

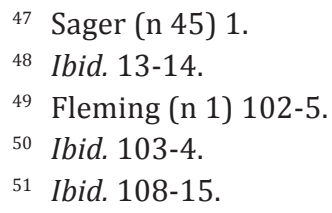


Esta revista forma parte del acervo de la Biblioteca Jurídica Virtual del Instituto de Investigaciones Jurídicas de la UNAM

sound like I am giving less weight to precedent than do some proponents of common-law constitutional interpretation. Yet I view precedent as an instantiation or approximation of the best understanding of our justice-seeking Constitution. ${ }^{52}$ With that observation, I hope to narrow the gap between Sager's and my accounts.

Sager observes that "there is something very attractive about fidelity" and that "[f]idelity mistakenly might be identified with some form of originalism". My aim was to reclaim the aspiration to fidelity from the originalists, reconceiving it as honoring our aspirational principles, not simply following our historical practices. I believe that there should be enough justice-seeking contained in that conception of fidelity to satisfy Sager. He encapsulates this conception well when he suggests that "fidelity offers us as a people the opportunity to be a better version of ourselves". ${ }^{33}$ To my mind, that seems to be a justice-seeking account of our constitutional practice.

\section{CONCLUSION}

In the title of his essay, Kersch cleverly speaks of originalism's "curiously triumphant death" ${ }^{54}$ I chuckled when I read that phrase. In this vein, I open my book by contending that originalists make spectacular concessions to their critics and then declare victory over them. ${ }^{55}$ As originalist Keith Whittington has acknowledged, originalism is like a character in a Night of the Living Dead movie. Just when you think it is dead, it proves to be alive.$^{56}$ I have no illusions that I have vanquished the hydra head of originalism, but I hope to have brought out some of the ways in which many originalists now acknowledge the need to make normative judgments in constitutional interpretation. And I hope to have made some progress in recasting and reclaiming the aspiration to fidelity to our imperfect Constitution.

52 Ibid. 102-5.

53 Ibid. 22.

54 Kersch (n 25) 1.

55 Fleming (n 1) 1.

56 Keith E. Whittington, 'It's Alive! The Persistence of the Constitution' (2002) 11 The Good Society 8-12. 
Esta revista forma parte del acervo de la Biblioteca Jurídica Virtual del Instituto de Investigaciones Jurídicas de la UNAM

JAMES E. FLEMING

VIII. BIBLIOGRAPHY

Balkin JM, 'The New Originalism and the Uses of History' (2013) 82 Fordham L. Rev. 641.

Barber SA \& FLEMING JE, Constitutional Interpretation: The Basic Questions xii, 155-70 (Oxford University Press 2007). SA, 'On Jim Fleming's Anti-Originalism' (2017) 11 Problema 21-30.

Baude W, 'Is Originalism Our Law?' (2015) 115 Colum. L. Rev. 2349, 2382.

Dworkin R, 'The Arduous Virtue of Fidelity: Originalism, Scalia, Tribe, and Nerve' (1997) 65 Fordham L. Rev. 1249.

- Freedom's Law: The Moral Reading of the American Constitution 2-3 (Harvard University Press 1996).

_ , Taking Rights Seriously 131-49 (Harvard University Press 1977).

Fleming JE \& McClain LC, Ordered Liberty: Rights, Responsibilities, and Virtues (Harvard University Press 2013).

(n 1) 89-90 (incorporating arguments from Lawrence G. Sager, Justice in Plainclothes: A Theory of American Constitutional Practice (Yale University Press 2004))

-, Fidelity to Our Imperfect Constitution: For Moral Readings and Against Originalisms (Oxford University Press 2015).

, Securing Constitutional Democracy: The Case of Autonomy (University of Chicago Press 2006).

Flores IB (n 19) 21-22 (quoting and discussing Lon L. Fuller, 'The Case of the Speluncean Explorers' (1949) 62 Harv. L. Rev. 616, 625-26).

IB, 'Constitutional Interpretation, Intelligent Fidelity, and (Im)Perfection: On James E. Fleming's Fidelity to Our Imperfect Constitution' (2017) 11 Problema 31-57.

Fuller LL, 'Positivism and Fidelity to Law-A Reply to Professor Hart' (1958) 71 Harv. L. Rev. 630. 
Fuller LL, The Morality of Law (Yale University Press 1969 rev. ed. 1977).

Ginsburg RB, 'Sexual Equality Under the Fourteenth and Equal Rights Amendments' 1979 Wash. U. L. Q. 161, 164).

Kersch KI, 'Originalism's Curiously Triumphant Death: The Interpenetration of Aspirationalism and Historicism in U.S. Constitutional Development' (2017) 11 Problema 59-83.

McClain LC, 'Reading DeBoer and Obergefell through the "Moral Readings versus Originalisms" Debate: From Constitutional "Empty Cupboards" to Evolving Understandings' (2017) 11 Problema 85-130.

Sager L, 'Delegation in our Justice-Seeking Constitution' (2017) 11 Problema 131-148. 